\title{
A BRIEF DESCRIPTION OF FEDERAL TAXES ON CORPORATIONS SINCE I86I
}

\author{
WIILAM A. SutherLAND*
}

The cost to the federal government of financing the Civil War created a need for increased revenue, and Congress in seeking new sources tapped theretofore untouched corporate and individual profits. The Act of July $x, 1862$, amending the Act of August 5, 186r, is the first law under which any federal income tax was collected and is considered to be largely the basis of our present system of income taxation.

The tax acts of the Civil War period ${ }^{1}$ contained provisions imposing graduated taxes upon the gain, profits, or income of every person ${ }^{2}$ and providing that corporate profits, whether divided or not, should be taxed to the stockholders. Certain specified corporations, such as banks, insurance companies and transportation companies, were taxed at the rate of $5 \%$ and their stockholders were not required to include in income their pro rata share of the profits. There were several tax acts during and following the War, but a description of the Act of 1864 will serve to show the general extent of the conporaie taxes of that period. The tax or "duty" was imposed upon all persons at the rate of $5 \%$ of the amount of gains, profits and income in excess of $\$ 600$ and not in excess of $\$ 5,000,7 \frac{1}{2} \%$ of the amount in excess of $\$ 5,000$ and not in excess of $\$ 10,000$, and $10 \%$ of the amount in excess of $\$ 10,000 .^{3}$ This tax was continued through the year $I 87 \mathrm{I}$, but in the last two years of its existence was reduced to $2 \frac{1}{2} \%$ upon all income.

- A.B, 1914, University of Virginiz; LL.B, 1917, Harvard University; A.M., 1919, University of Wisconsin. Member of Georgia and Distriat of Columbia Bars. General Solicitor, Tennessec Vallts Authority, 1933-1934. Member, Committee on Federal T2xation of Corporations, National Tax Association. Member of Council, Tax Section, American Bar Association.

This article has been large'y derired from 2 mernorasodum on the same subject prepared by the ame author for the Committe on Federal Taxation of the National Tax Association and published as an appendix to its report in NAr. TAx Ass's, Procosenisce, 1938, p. 632. The author wishes to acknowledge his indebtednes: to his associate, Randolph W. "Thrower, for his very valuable assistance in the preparation of the original memorandum and this condensation.

I Act of Aug. 5, 186 $\mathrm{T}, \mathrm{C}$ 45, 5549-5I, 12 SrAT. 309, which was amended, continued in force, and -modified by Act of July 1,1862 , C. 119, $3589-93$, 12 STAT. 473; Act of June 30, 1864, c. 173, $35 \times 16-123$; 13 Stat. 281; Act of Merch 3, 1865, c. 78, 13 Stat. 469; Act of July 13, 1866, c. 184, 59, 14 Stat. 10x; Aat of March 2, 1867, c. 169, S13, I4 STAT. 477; and Aet of July 14, 1870, c. 255, 356-17, 16 STAT. 257. It expired in $18 \%$. (Reference will be to Act of 1864 even though similar provisions are contained in other acts of this period.)

"The definition of "person" was expressly made to include corporations except where otherwise stated or when "manifestly incompatible" with the provisions in which it was userl. See 582, Act of 1864 . However, it does not appear that ang attempt was made to subject corporations to this tax.

"5116. (Before any tax was collectible under this act, it was amended by the Act of 1865, making the rates of tax $5 \%$ on incomes over $\$ 600$ and not over $\$ 5,000$ and $10 \%$ on the excess over $\$ 5,000$.) 
None of these Civil War taxes was found by the Supreme Court to be unconstitutional, although the case of Brainard v. Hubbard, upholding Section II7 of the 1864 Act, as amended, was disapproved in a later Supreme Court case.

In 1894 there was imposed another income tax, this time upon corporations and individuals alike, at the rate of $2 \%$ of gains, profits, or income, from whatever source obtained. A $\$ 4,000$ credit against income given to individuals was not extended to corporations. Dividends received were excluded from both corporate and individual incomes. The income tax provisions being invalid as to the greater part of the intended sources of income, they were held by the Supreme Court to be wholly inoperative and void. :

Again in I909, Congress in the Payne-Aldrich Tariff Act imposed what looked suspiciously like an income tax upon corporations. The tax was carefully referred to, however, as a "special excise tax with respect to the carrying on or doing business," and was at the rate of $r \%$ upon the entire net income, exceeding $\$ 5,000$, of every corporation, joint stock company and association organized for profit and having a capital stock represented by shares. Dividends received from other corporations subject to the tax were excluded from net income. This tax was in effect for the years 1909 through I9I2, and by the Act of 1913 was continued in effect for the first two months of that year. The constitutionality of the 1909 Act was upheld by the Supreme Court. ${ }^{\text {T. }}$

The Sixteenth Amendment, adopted February 25, 1913, gave to Congress the power, and only a few years later the World War gave to Congress the need, to levy tremendous undisguised income taxes upon individuals as well as corporations. As rates applying to both individuals and corporations were increased, greater care was taken to reach those gains and profits considered to be properly taxable and to insert remedial provisions where general provisions operated harshly and not in accordance with the intent of Congress. Attempts were made to prevent use of the corporate form to enable shareholders to avoid high taxes upon their individual incomes. "Excess" profits were especially singled out for attention during and immediately following the War. In subsequent acts, other types of income have been given special attention. All this has resulted in revenue acts that are long and complicated and present a patchwork of cross references and technical terms, requiring careful, analytical study.

The Revenue Act of 1913, passed on October 3, rgr3 and applicable from March I, 1913 to December 3r, 1915, was the first act passed under the Sixteenth Amendment. It imposed upon corporations a tax at the flat rate of $1 \%$ of net income. No exemption such as the $\$ 5,000$ exemption in the Act of 1309 was given. Net income was defined very much as it was under the 1909 Act.

12 Wall. I (U. S. 1870).

${ }^{B}$ Eisner v. Macomber, 252 U. S. 189, 218 (1920). See the following cases discussing these statutes: Stockdale v. Atlantic Ins. Co., 20 Wall. 323 (U. S. 1873); Michigan Cent. R. Co. v. Slack, 100 U. S. 595 (1879); Springer v. U. S., 102 U. S. 586 (1880); U. S. v. Erie R. Co., 106 U. S. 327 (1882).

- Pollock v. Farmers Loan \& Trust Company, 157 U. S. 429 (1895); 158 U. S. 601 (1895).

${ }^{\top}$ Flint v. Stone Tracy Company, 220 U. S. I07 (Igro). 
In drafting the Revenue Act of 1913, the legislators anticipated and attempted to prevent a type of tax avoidance which has been a constant problem to Congress ever since. That act prescribed that the income of individual shareholders should include their pro rata share of the net income of corporations "formed or fraudulently availed of" for the purpose of preventing the imposition of the surtax, or "additional tax" as it was then called, upon individuals by means of accumulating the gains and profits of such corporations and not distributing them. The fact that a corporation was a "mere holding company" or that gains and profits were permitted to accumulate beyond the reasonable needs of the business was made prima facie evidence of the interdicted purpose. These provisions were not substantially changed before 1921.

The Act of 1913 exempted corporate dividends from the net income of individuals for normal tax purposes, but not for "additional tax" purposes. This exemption was not given to corporations. It is to be noted that in this act, as well as in the 1916 Act, normal rates on corporations and individuals were the same.

Little change was made in the Revenue Act of 1916 as it applied to corporations, except that the rate of tax was increased to $2 \%$. The normal tax rate on individuals was likewise made $2 \%$. The corporate tax rate of $2 \%$ contained in the 1916 Act was made applicable to 1917 by the 1917 Act amending the 1916. Act. An additional tax of $4 \%$ on net income less dividends received was imposed upon corporations. Here the identity between the rates of the corporate income tax and the normal tax on individuals disappeared and in all subsequent acts the former rato has exceeded the latter.

The I917 Act contained a provision placing on every corporation, joint stock company or association, including insurance companies, a tax of $10 \%$ of the amount of the total net income received during the year which remained undistributed six months after its end. The tax was not made to apply to that portion of undistributed net income actually invested or employed in business or retained for employment in the reasonable requirements of the business or invested in obligations of the United States issued after September 1, 1917.

The 1917 Act provided that distributions by corporations should be deemed to have been made from the most recently accumulated profits and should constitute income to the distributee for the year in which received, but "shall be taxed to the distributees at the rate prescribed by law for the years in which such profits or surpluses were accumulated by the corporation. ..." This marked the first legislative attempt to designate the source and nature of corporate distributions.

In the Revenue Act of 1918 , which was in effect through 1920 , the income tax on corporations was imposed at largely increased rates, namely, $12 \%$ for 1918 and $10 \%$ for subsequent years. Provision was made that the net loss suffered in any year beginning after August 3r, 1918, and ending prior to January 1, 1920, arising from an enterprise entered into for war purposes, should be applied to reduce net income in the preceding year and, if in excess of that income, to reduce to the extent of the 
excess the net income of the succeeding year also. Corporations were not taxed for either income or war-profits and excess profits tax purposes upon dividends from other corporations subject to these taxes.

An important addition to income tax law was the provision in the 1918 Act for non-recognition of gain or loss upon an exchange of stock or securities for new stock or securities of no greater aggregate face or par value, if in connection with a reorganization, consolidation or merger. When the aggregate par or face value of the new stock was in excess of that of the old stock, the excess was treated as gain to the extent that the fair market value of the new stock exceeded the cost, or March I, :913, value of the old stock. In later acts, considerable attention has been given to provisions making tax-free exchanges possible in reorganizations, consolidations and mergers, as a comparison of the 1918 Act with recent acts will reveal.

Section 218 (e) of the 1918 Act introduced another new measure into tax law. It provided a tax on the income of personal service corporations to the shareholders in their individual capacities, to the extent of the distributive share of each in the net income of the corporation. A personal service corporation was defined as a corporation whose income was obtained chiefly from the activities of the principal owners or stockholders who themselves were active in the business and whose capital was not a material income-producing factor. Personal service corporations- were not rhemselves subject to the income tax or to the war profits and excess profits taxes. Their special treatment was continued in the Revenue Act of I92I but not thereafter.

Of far greater effect upon corporations earning a large return on their capital than any of the other provisions of the Acts of 1917 and 1918 are those prescribing excess profits and war profits taxes. ${ }^{8}$ The excessiveness of the profits was determined in part by comparing such profits with the annual profits made during a selected period prior to the beginning of the World War, and in-part by reference to certain arbitrary rates of return on invested capital which were assumed to be "normal."

The war-time excess profits tax was imposed, in addition to other taxes, on corporations, partnerships, and individuals for 1917 , and on corporations alone for the years 1918 through 1921 . It was imposed on corporations at increasing rates on incomes falling within certain percentages of the "invested capital" There was a credit allowed against net income of $\$ 3,000$ plus a certain rate of return on invested capital. Under the 1917 Act, a corporation was allowed as the return upon its "invested capital" the same rate of return obtained in the "prewar" years of xiri through 1913, provided that this rate was not less than $7 \%$ nor more than $9 \%$. For example, if a concern with an invested capital in the "prewar" period, as well as in the taxable year, of $\$ 1,000,000$ earned in the "prewar" period an average return of $9 \%$, its credit would be $\$ 3,000$ plus $9 \%$ of its invested capital for the taxable year, or $\$ 93,000$. The net income in excess of the $\$ 93,000$ would be subject to the excess profits tax. A complicated definition was given of "invested capital." Under the 1918 and 1921

- Act of 1917. Tit. II; Act of 1918, Tiz. II. An excess profits tax imposed by the Act of March 3 , 1917, 39 ST.AT. 1000, w2s superseded by the Act of OCt. 3,1917, \$214 of which expressiy repealed the excess profits tax provisions of the carlier 2 a. 
Acts, no use was made of the "prewar" period for excess profits tax purposes, and a credit was provided of $\$ 3,000$ plus $8 \%$ of the "invested capital" for the taxable year.

The excess profits tax for the rgr $j$ taxable year was imposed at rates graduated from $20 \%$ of the amount of taxable income not in excess of $15 \%$ of the invested capital to $60 \%$ of the amount of taxable income in excess of $33 \%$ of the invested capital. Under the 1918 Act, the tax was increased for that year to $30 \%$ of the amount of taxable income not in excess of $20 \%$ of the invested capital, and $65 \%$ of the amount of such income in excess of $20 \%$ of the invested capital. For 1919, 1920, and 1921 , the excess profits tax was reduced from the $30 \%$ and $65 \%$ rates in effect for the year 1918 to $20 \%$ and $40 \%$.

Provisions were adopted in these acts to avoid injustices and hardships. Where the returns of a corporation were abnormally low in the "prewar" years or where it was found impossible satisfartorily to ascertain "invested capital," the Commissioner of Internal Revenue was authorized to refer to representative concerns in the computation of the allowance for normal return. Similar treatment was extended in the 1918 and 192x Acts to corporations showing that, if no such relief were given, the tax would, due to abnermal conditions affecting the corporate capital or income, work an exceptional hardship. Great discretion here was left to the Commissioner to determine first, what corporations were entitled to "special assessments," and second, what concerns should be chosen as "representative concerns" under the Act.

Another war-time tax closely associated with the war-time excess profits tax is the war profits tax imposed upon all corporations generally for 1918 , and for 1919 through I921 upon net incomes in excess of $\$ 10,000$ derived from government contracts made between April 6, I9I7 and November II, I9I8. The tax was computed for 1919 through 1921 by figuring the tax upon the total net income at the rates provided for all corporations under the excess profits and war profits tax provisions of the 1918 Act and taking that percentage of the total tax so obtained which the net-income from the government contracts bore to the entire net income.

The war profits tax was equal to the sum by which $80 \%$ of the net income in excess of the war profits credit exceeded the excess profits tax for the taxable year. A corporation was given a credit against net income of $\$ 3,000$, plus what it might have been expected to earn in the taxable year judging by its earnings in a comparative pre-war period, but not less than $10 \%$ of the "invested capital," and all over that was subjected to the highly confiscatory tax of $80 \%$, a deduction being given for the excess profits tax. Both the war profits and the excess profits taxes constituted a deduction for ordinary income tax purposes.

There was imposed by th: Revenue Act of $\mathrm{rg} 18$ and continued by the Acts of 1921, and I924, a capital stock tax at the annual rate of $\$ 1$ for each $\$ 1,000$ of the "fair average value" of the capital stock of the taxpayer in excess of $\$ 5,000$. This tax was in effect until repealed by the Revenue Act of 1926 and did not reappear until associated with the excess profits tax in the NIRA. 
After the war period passed, it was the general tendency of tax acts, beginning with the 1921 Act and continuing through the 1928 Act, to reduce taxes from the war level and to improve the revenue acts, not by any startling changes, but by remedial provisions intended to eliminate any harsh effect of existing provisions and to prevent tax avoidance. The revenue of the national government was high in relation to its expenses, and the difficulties of keeping the national budget in balance and reducing the national debt were not serious.

The corporate income tax as imposed by the Revenue Act of 1918 for the years 1919 and 1920 was not materially changed by any subsequent acts during the Twenties. An increase of $2 \frac{1}{2} \%$ was made in the rg21 Act to offset in part the loss of the excess profits tax revenues. The table appended to this article shows the corporate tax rates during these years.

In the Revenue Acts from I921 to the present time, the simple statement in the Act of 1918 providing for non-recognition of gain or loss upon security exchanges in mergers, consolidations, and reorganizations has been amplified and greaty extended. For this there have been two reasons. One has been the desire to extend the benefits of non-recognition of gain or loss to those transactions where in practical effect there was either a mere rearrangement of evidences and types of ownership without any change in the fact of ownership and thing owned or a merger of ownership without any immediate realization of gain. The other has been to eliminate the possibility of the reorganization provisions being availed of so realize, free from tax, real and not merely fictional gains.

In the Ig2r Act, a new type of provision was made to prevent the misuse of corporations to evade surtaxes on individuals. Upon corporations formed or availed of to evade surtaxes it placed a tax, in addition to normal tax, of $25 \%$ of net income. The presumptions as to holding companies and unreasonable accumulation of profits were retained. However, where all the stockholders of a corporation agreed, the Commissioner, in lieu of income, war profits and excess profits taxes, could tax them on their distributive share of the corporation's net income. In the Revenue Act of 1924 the tax was increased from $25 \%$ of net income to $50 \%$ and to net income was added the amount of the dividends received from domestic corporations and otherwise allowed as a deduction. No provision was made for the reporting of corporate income by the stockholders, a privilege restored by the Act of 1926 and continued in the 1928 Act. Amounts so included by shareholders in their income were to be treated as dividends received. The rate of tax remained unchanged.

The matter of consolidated returns filed by affiliated corporations received considerable attention following the War. Under the 1917 Act corporations so affliated as to constitute in actual effect only one corporation were required by treasury regulation to file a consolidated return whenever the Commissioner found this necessary to determine more equitably the invested capital or taxable income. The rg18 Act made mandatory that all corporations thus affiliated file consolidated returns. Under the Revenue Acts of 1921,1924 and 1926, the filing of such returns was made optional 
with the corporations. The act of 1928 continued this privilege for that year, but attached the condition to its grant for 1929 and subsequent years that the corporation agree to accept all regulations for such years prescribed for the purpose of insuring that the income of consolidated corporations should be clearly reflected and that tax liability should not be avoided.

In the Revenue Act of 1932 there was an increase in the rate of taxation from $12 \%$ to $133 \% 4$. Under this act, the transfer of stock or securities by a domestic corporatior, as well as by an individual, a partnership or a domestic trust, to a foreign corporation, trust or partnership as paid-in surplus or contribution to capital, was taxed at the rate of $25 \%$ upon the excess of the value of the stock over its basis in the hands of the transferor. This transfer tax was not to apply if the transferee was a non-profit organization exempted from tax or if, prior to the transfer, it was established that the transfer was not made to avoid income tax. This tax is still in effect.

Provisions as to the filing of consolidated returns by affiliated corporations were continued in the 1932 Act, but an additional income tax of $3 / 4$ of $1 \%$ was placed on corporations electing to file consolidated returns. The $50 \%$ tax upon the net income of corporations unreasonably accumulating surplus was also retained.

The-Revenue Act of 1932 was applicable to the.year 1932 and, as amended by the NIRA, to the year 1933 as well. The principal change relating to the corporate income tax was the withdrawal of the deduction allowed under prior acts for net losses incurred in the preceding year. The additional tax of $3 / 4$ of $1 \%$ placed upon corporations filing consolidated returns under the $193^{2}$ Act was increased by the NIRA to $1 \%$ for the taxable years 1934 and 1935 .

The NIRA reintroduced to corporate taxation the capital stock and excess-profits taxes, but they were entirely different in many respects from similarly named taxes of prior years. A capital stock tax was imposed at the rate of $\$ 1$ for each $\$ 1,000$, not of the actual value of the capital stock, but for each $\$ 1,000$ of any value which a corporation might choose to place upon its capital stock. However, to insure the fact that no less than the normal rate of $\$ 1$ upon each $\$ 1,000$ of the fair value of the capital stock should be obtained, the excess profits tax was imposed at the rate of $5 \%$ upon net income in excess of $121 / 2 \%$ of the "adjusted declared value" of the capital stock. It was provided in this act that a value declared in the first year should be retained for subsequent years with necessary adjustment for such matters as distributions out of capital, additions to capital, paid-in surplus, and profits or deficits. The usual class of nonprofit organizations was exempted, as well as inactive corporations. In passing it may be noted that the life of the capital stock and excess profits taxes under the NIRA was to be terminated by Presidential proclamation of the date of the end of the first fiscal year after the 1933 fiscal year in which the receipts of the federal government exceeded the expenditures, or of the repeal of the Eighteenth Amendment to the Constitution, whichever was earlier. The Amendment's repeal was proclaimed on December 5, 1933. 
The 1934 Act extended the life of the capital stock tax and excess profits tax provisions as imposed by the NIRA. The taxpayer was given the privilege of redeclaring the value of his capital stock for the year ended June 30, 1934. As will be noted, the capital stock and excess profits taxes and their interdependency has been continued to the present.

In the Revenue Act of 1934 , the normal tax was imposed upon corporations at the same rate as that prescribed in the 1932 Act, namely $133 / 4 \%$, with the exception that in the case of consolidated returns of railroad corporations the rate was made $15 \%$. The privilege of making consolidated returns was limited under the new act to railroad corporations, and the additional tax of $2 \%$ was in payment for this privilege. Under the 1934 Act, there was also introduced a very important limitation upon the capital losses of all taxpayers, including corporations, excepting certain sales by banks or trust companies, of $\$ 2,000$ plus gains from sales or exchanges of capital assets.

Section 35I of the Revenue Act of 1934 is the culmination of the first of several outstanding efforts on the part of the present administration and the committees in Congress which consider tax bills to eliminate what is termed as the inequity of the escape by individuals from surtaxes through the retention of corporate profits without distribution. It has been seen that this means of evading taxes was anticipated by those who drafted the first revenue act under the Sixteenth Amendment. Under that act, it was presumed that a holding company was formed or availed of for the. purpose of evading surtaxes on individuals. This presumption has been retained in later acts, whether the acts treated such accumulated profits as if distributed and thus taxable to the shareholders, or attempted to force distributions and recoup taxes otherwise lost to the government by heavy taxes upon corporations used for tax avoidance. For a corporation to be subject to these heavy taxes, intent to evade had always been a necessary condition and the difficulty of proving this intent greatly impaired the effectiveness of the acts. With this in mind, those drafting the Revenue Act of $x 934$ imposed upon personal holding companies as defined a heavy surtax based upon undistributed profits earned during the year. The intent responsible for the accumulation in the particular case was immaterial. Personal holding companies were becoming popularly known as "incorporated pocketbooks," and the fact of their existence, accompanied by actual accumulations, was considered sufficient evidence of the intent.

The new surtax on personal holding companies was imposed at the rate of $30 \%$ of that portion of "undistributed adjusted net income" under $\$ 100,000$, and $40 \%$ of that portion over $\$ 100,000$. "Undistributed adjusted net income" involved adjustments of net income to arrive at the true income which a corporation might be considered to have available for distribution after the allowance of $20 \%$ for retention of income. Shareholders could relieve the corporation from this tax by including in their returns their entire pro rata share of the income of the corporation. A personal 
holding company was defined generally as being a corporation which received at least $80 \%$ of its income from royalties, dividends, interest, annuities and (except in the case of regular dealers in stocks or securities) gains from the sale of stocks or securities, and $50 \%$ of whose stock was owned at any time during the last half of the taxable year, directly or indirectly, by not more than five individuals. Provisions were made to measure ownership only by the real owners of the company and to prevent distribution of stock in a family for the purpose of bringing the number of owners above five.

The surtax on corporations improperly accumulating a surplus and not distributing it was retained in the 1934 Act with certain changes which, it was hoped, would make it more effective, since in the past it had been of little use. Personal holding companies were excluded from the application of this tax. The tax rate was changed from the flat rate of $50 \%$ in effect since 1924 to a tax of $25 \%$ of the amount of the "adjusted net income" not in excess of $\$ 100,000$ plus $35 \%$ of the amount of the "adjusted net income" in excess of $\$ 100,000$. Under prior acts, a corporation distributing $50 \%$ and retaining $50 \%$ of its net income to avoid to that extent the imposition of surtax upon its shareholders, would have been subject to a penalty tax of $50 \%$ of entire net income, or $100 \%$ of undistributed income. It was entirely possible under these prior acts for the amount of the tax to have been several times larger than the amount of the income improperly retained. This situation was corrected by permitting a deduction, in computing "adjusted net income," of amounts distributed to shareholders.

The Revenue Act of 1935 was passed in answer to a tax message from the President to Congress dated June 19 , 1935, in which he contended that the advantages conferred by the government upon corporations increased in value as the size of the corporations increased, that the advantages gained by the large corporations engaged in interstate business were derived through the federal government chiefly and that the principle of taxation in accordance with ability to pay, as well as in accordance with benefits received, should apply to corporate taxation much as it had been applied to the individual income tax. The President recommended a graduated rate scale for corporate income instead of a uniform rate. To prevent the larger corporations from escaping the tax in the higher brackets by doing business through numerous subsidiaries or affiliates, a tax on dividen's received by corporations was advised. The President also urged the desirability of simplifying corporate structure by "eliminating superfluous holding companies.

As shown in the appended table, Congress acceded to the proposal for a graduated rate scale on corporate income and reduced the deduction allowed to corporations for dividends received. Furthermore, to encourage liquidation of what were considered unnecessary holding companies, a section was included in the 1935 Act providing for the non-recognition of gain or loss to a corporation upon the complete liquidation of its subsidiaries. 
The 1935 Act allowed to corporations a deduction for charitable or other contributions made during the year not to exceed $5 \%$ of ret income. This deduction has been continued in later acts.

The surtax on personal holding companies introduced in the 1934 Act was increased, the new rates being graduated from $20 \%$ of the amount of the taxable income not in excess of $\$ 2,000$ to $60 \%$ of the amount in excess of $\$ 1,000,000$. Amendments permitted a corporation to receive $d$ deduction for distributions made out of earnings and profits during the year, even though an operating deficit existed and was carried over from prior years.

The 1935 Act increased the capital stock tax rate from $\$ 1$ to $\$ 1.40$ per $\$ 1,000$ of the new "adjusted declared value" of the capital stock. A new excess profits tax was imposed at the rate of $6 \%$ of net income in excess of $10 \%$ and not in excess of $15 \%$ of the adjusted declared value of the capital stock of the corporation, and $12 \%$ of net income in excess of $15 \%$.

The 1935 Act, with the exception of sections not mentioned in this paper, was applicable only to taxable years beginning after December 31, 1935; and before it became effective it was superseded by the Revenue Act of 1936 .

In the message which led to the 1936 Revenue Act, the President pointed out that the evil of evasion of surtaxes through the accumulation of profits in a corporation was an old and growing one, and that the Treasury had estimated that during the calendar year 1936 over four and one-half billion dollars of corporate income would be withheld from stockholders. He stated that this retention of profits not only enabled shareholders to escape surtaxes, but also thereby gave to incorporated businesses great advantages over those unincorporated. To eliminate this "serious twofold inequality," the President suggested a tax on undistributed corporate income, including intercorporate dividends, and a repeal of the existing tax on corporate income and of the capital stock and excess profits taxes.

It will be recalled that in the Civil War taxes, the end for which the President was striving had been reached. That end is the taxation to the individual owners of businesses, whether incorporated or not, of their pro rata share of the profits. It has been pointed out that, years later, the 1913 and 1916 Revenue Acts provided that where a corporation was fraudulently formed or availed of to avoid taxes upon its stockholders, its net income should be considered, for purposes of determining the net income of the respective shareholders, as though it had been distributed. The Act of 1917 taxed at $10 \%$ corporate profits remaining undistributed and unused for specified purposes six months after the end of the taxable year. Furthermore, provision was made in the World War tax acts that the net income of a personal service corporation should be considered in determining the net income of its shareholders as if it had been distributed.

The Revenue Act of 1936 as finally adopted by Congress was not entirely in accordance with the suggestions of the President. The House bill, it is true, had been, but the Senate insisted upon and obtained important modifications of the House's 
undistributed profits tax as well as a continuation of a corporate income tax at graduated rates and the capital stock and excess profits taxes."

The undistributed profits tax as passed provided. for the determination of an "adjusted net income" which represented the amount available for distribution. Certain credits were then allowed against this, including dividends paid with a two-year dividend carry-over, and earnings withheld from payment of dividends under a written contract executed prior to May 1,1936 . The income resulting was defined as the "undistributed net income," and the tax was imposed upon this amount at rates graduated from $7 \%$ of the portion of the "undistributed net income" which was not in excess of $10 \%$ of the "adjusted net income" to $27 \%$ of that portion in excess of $60 \%$. An additional credit was given to corporations with "adjusted net incomes" less than $\$ 50,000$.

Other changes in the tax on corporations were made by the Revenue Act of 1936. A greater degree of graduation was made in applying the normal tax, the new tax progressing from $8 \%$ on "normal tax income" less than $\$ 2,000$, to $15 \%$ on such income in excess of $\$ 30,000$. The deduction or credit against net income for dividends received from domestic corporations was reduced to $85 \%$ of such dividends.

The tax of $25 \%$ and $35 \%$ imposed by the 1935 Act upon corporations used for surtax avcidance was amended in the 1936 Act by reducing the rates upon corporations subject to the undistributed profits tax to $15 \%$ and $25 \%$ of corporate net income under $\$ 100,000$, and over $\$ 100,000$, respectively. The relief to be obtained by the election of shareholders to report corporate income at the time of filing their returns was limited by withholding its benefits from corporations whose stock to the extent of $11 \%$ or more was owned by other corporations. Under the 1936 Act the surtax on personal holding companies was continued at lower rates ranging from $8 \%$ of the amount of the undistributed adjusted net income less than $\$ 2,000$ to $48 \%$ of the amount in excess of $\$ 1,000,000$.

The capital stock and excess profits taxes were retained with the change that the capital stock tax was reduced from $\$$ I.40 to $\$$ I per $\$ 1,000$ of the adjusted declared value of the capital stock. This change was made as an amendment to the 1935 Act.

After the passage of the Revenue Act of 1936 , the drive to eliminate the practice of many corporations to retain substantial portions of their income was continued for the purpose of forcing all earnings, whether of incorporated or unincorporated businesses, to be taxed to the real owners both at normal and surtax rates. On June $x$, 1937, the President in a message to Congress stated that there were several devices resorted to by taxpayers to permit them to escape what were termed to be their just taxes. Chief attention was given to the use of personal holding companies for such purposes. With the intent of striking a more effective blow at such practices, Congress passed the Revenue Act of 1937, which increased greatly the rates applicable to personal holding companies (the definition of which was extended) to $65 \%$ of the amount of the undistributed adjusted net income not in excess of $\$ 2,000$ and $75 \%$

- For discussion, see Report of Senate Finance Committee on Revenue Bill of 1936, SEN. REp. No. 2156, 74th Cong., 2d Sess. (1936) 4-6. 
of the amount in excess of $\$ 2,000$, and eliminated the net loss carry-over. Moreover, the $20 \%$ of "adjusted net income" allowed to such companies as "grace," probably on the assumption that a retention of this much could very well be reasonable in some cases, was eliminated. In addition, no provision was made for a company to be relieved from the payment of the tax by any agreement of its stockholders to report in their returns their pro rata share of its net income.

The effect of the extension of the definition of a personal holding company was to reach what were commonly referred to as "incorporated talent" companies, the highly publicized incorporation of yachts, city residences, country estates, etc., and the receipt by corporations of income from estates and trusts. The definition of personal holding company income was extended to include income from rents, unless such income constituted $50 \%$ or more of the entire gross income. It was also provided that once a corporation fell within the definition of a personal holding company, it should be so considered in every year thereafter until certain conditions as to income and stock ownership were met.

It was presented to the tax committees of Congress that foreign personal holding companies had been increasingly popular as loopholes for tax avoidance. The 1937 Act established a method of taxing to the shareholders of such a company their share of its undistributed net income.

As the committees of Congress charged with the drafting of the Revenue Act of 1938 met to consider the effects of the then existing law, they were faced with strong protest against the operation of the undistributed profits tax under the 1936 Act. As listed in the report of the Ways and Means Committee on the Revenue Bill of 1938 , "the principal complaints against the surtax on undistributed profits in the form imposed by the Revenue Act of 1936 may be summarized as follows: (I) The surtax discourages, in many cases, legitimate business expansion, and, therefore, has an adverse effect on employment. (2) It puts a penalty on corporations which find it necessary to use current earnings in the payment of debts. (3) It burdens the small and weak corporations more than the large and financially strong corporations. (4) It is unfair to corporations with impaired capital which under state law cannot legally declare dividends. (5) The relief provisions applying to corporations having contracts not to pay dividends or requiring the use of current earnings for the payment of debts are so restrictive as to provide relief only in rare cases, although many other cases equally meritorious receive no relief."10

The bill as passed combined the income tax with a much smaller undistributed profits tax. The maximum rate of corporate income tax was fixed at $19 \%$ with some reduction in this tax to be based upon the amount of dividends distributed. The maximum reduction was $2 \frac{1}{2} \%$ so that the minimum tax upon corporations under the 1938 income tax law was $161 / 2 \%$. Among the salutary provisions were the liberal credits given for purposes of determining the $21 / 2 \%$ undistributed profits tax, including a two-year dividend carry-over, a one-year net operating loss carry-over, a deficit

${ }^{10}$ H. R. Rep. No. 1860, 75th Cong., 3d Sess. (1938) I. 
credit, a consent dividend credit, and a credit for amourits set aside to cover certain indebtedness. As recommended by both House and Senate committees, special relicf provisions were made for corporations with incomes less than $\$ 25,000$, and provisions also were adopted to provide adjustments for corporations with incomes slightly in excess of $\$ 25,000$. Corporations with net incomes of less than $\$ 25,000$ were not subject to the tax discussed above, but were taxed at rates progressing from $121 / 2 \%$ of income less than $\$ 5,000$ to $16 \%$ of such income in excess of $\$ 20,000$. The total tax on a "special class net income" of $\$ 25,000$ amounts to $\$ 3,525.00$, or $14.1 \%$. .

The surtax on corporations improperly accumulating surplus was continued in the 1938 Act in much the same form as in the 1936 Act, the principal difference being that, whereas in the 1936 and prior Acts the unreasonable accumulation of profits established merely a presumption of evasion, such an accumulation under the 1938 Act was made determinative of the purpose to avoid surtaxes unless the corporation is able to prove by the clear preponderance of evidence that this was not the purpose of the accumulation.

Little change was made in the tax on personal holding companies provided in the 1937 Act. Personal finance companies were excluded from the definition of a "personal holding company," and corporations making consolidated returns were brought within the definition if the stock ownership of the parent corporation and the income of the affliate group fall within the personal holding company classification.

The capital stock and excess profits taxes were retained with the single significant change that the corporation could declare anew the value of its capital stock for the year ended June $30,193^{8}$, and, what is important, for each third year thereafter.

The corporate income tax provisions of the $193^{8}$ Act were not applicable to any taxable year beginning after December 31, 1939.

The movement toward revenue laws more acceptable to business interest, which had been started in the Revenue Act of 1938, as a reversal of the trend reflected in the several preceding revenue acts, was continued with greater force in the Revenue Act of 1939. Probably the most notable change made was the complete elimination of any element of undistributed profits tax. Although the tax had been reduced in the 1938 Act to a maximum of $2 \frac{1}{2} \%$, it was recognized that this tax, though small and relatively unimportant as to revenue, was a major tax "irritant." 11 The new act imposes, for taxable years beginning on or after January $\mathrm{I}, 194^{\circ}$, a flat corporate tax of $18 \%$ upon corporations with incomes above $\$ 25,000$. Corporations with incomes less than $\$ 25,000$ were taxed, as under the $1938 \mathrm{Act}$, at rates graduated from $121 / 2 \%$ to $16 \%$, and adjustments were provided for corporations with incomes slightly in excess of $\$ 25,000$.

Another change in the Act of 1939 of great importance was the reintroduction of the practice of permitting corporations to carry over for two years net operating business losses. It was pointed out in the "Report of the Conmittee on Ways and Means on the Revenue Bill of 1939" that the elimination of this carry-over had

"See Testimony of Secretary Morgenthau, Hearings before the House Ways and Means Committee, 76th Cong., 1st Sess. (1939) 5. 
placed a heavy burden on a business which had alternating profits and losses, 25 contrasted with a business maintaining stable profits, even though over a period of years the average income of the two concerns might be the same.

Earlier revenue acts beginning with the 1934 Act had allowed corporations to deduct capital losses only to the extent of $\$ 2,000$ plus capital gains. The excess of capital losses over capital gains plus $\$ 2,000$ could not be availed of as a deduction in the year of loss or in any other year. The House committee pointed out that this was a tax irritant which had handicapped many corporations, and in the passage of the 1939 act the committee's recommendation was accepted, allowing to corporations other than foreign and domestic personal holding companies full deduction for income tax purposes of long-term capital losses, i.e., losses on capital assets held for more than 18 months, and allowing short-term capital losses to be deducted from short-term capital gains, any excess of losses to be applied against short-term capital gains of the following year in an amount not exceeding the net income for the earlier year.

To remedy the hardship arising from the provision of the $193^{8}$ Act requiring a corporation to forecast its profits over a three-year period, Congress provided that those corporations which had declared an insufficient value for capital stock purposes may increase such value for the capital stock tax years ending June 30, 1939, and June 30, 1940. This should relieve many corporations from large excess profits tax liabilities for these two years.

The 1939 Act contains a new provision relating to the treatment of income resulting from the discharge of corporate indebtedness. The provisions as to discharge are intended to give to railroads and other corporations in an unsound financial condition, whose bonds can now be purchased at less than their face value, an opportunity to liquidate their indebtedness without the recognition of gain.

The tax provisions of the 1939 Act were enacted as amendments to the Internal Revenue Code with no fixed date for expiration.

There is set forth in the table showing corporate tax rates since 1909, with the specific exemption for each year, if any, and, for comparison, normal tax rates on individuals since 1913. This summary shows also whether or not deductions or credits were given to corforations and individuals for dividends received. 
Sumalary of Corporate and Individual Tax Rates, Etc, Since $1909^{*}$

\begin{tabular}{|c|c|c|c|c|c|}
\hline Year 1 & Tax Ats & $\begin{array}{l}\text { Corpora- } \\
\text { tion Tax }\end{array}$ & $\begin{array}{l}\text { Normal Tax ox } \\
\text { Indiziduals }\end{array}$ & $\begin{array}{l}\text { Deduction of } \\
\text { Diridends for } \\
\text { Corporate and } \\
\text { Normal Taxes }\end{array}$ & $\begin{array}{l}\text { Specific } \\
\text { Corporate } \\
\text { Exemption }\end{array}$ \\
\hline 1909-1912 & $1909 . . .$. & $1 \%$ & none & Corporations & $\$ 5,000$ \\
\hline $\begin{array}{l}1913-1915 \\
1916\end{array}$ & $\begin{array}{l}1913 \ldots \ldots \\
1916 \ldots \ldots\end{array}$ & $\begin{array}{l}1 \% \\
2 \%\end{array}$ & $\begin{array}{l}1 \% \\
2 \%\end{array}$ & $\begin{array}{l}\text { Individuals only } \\
\text { Individuals only }\end{array}$ & $\begin{array}{l}\text { nane } \\
\text { nane }\end{array}$ \\
\hline $\begin{array}{l}1917 \\
1918\end{array}$ & $1917 \ldots \ldots$ & $\begin{array}{l}2 \% \\
4 \% \\
12 \%\end{array}$ & $\begin{array}{l}2 \% \\
2 \% \\
6 \% \text { on } \$ 4,000 \\
12 \% \text { on balance }\end{array}$ & $\begin{array}{l}\text { Individuals only } \\
\text { both } \\
\text { both }\end{array}$ & $\begin{array}{l}\text { DODC } \\
\text { DODC } \\
\$ 2,000\end{array}$ \\
\hline $2919-1920$ & $1918 . . .$. & $.10 \%$ & $\begin{array}{l}1 \% \text { on } \$ 4,000 \\
8 \% \text { on balance }\end{array}$ & both & $\$ 2,000$ \\
\hline 1921 & $1921 . . .$. & $10 \%$ & $\operatorname{sanc}$ & both & $\begin{array}{l}32,000 \text { if net } \\
\text { income lew } \\
\text { than } \$ 25,000\end{array}$ \\
\hline $1922-1923$ & $1922 \ldots .$. & $12 \% \%$ & same & both & same \\
\hline 1924 & $1924 \ldots .$. & $1212 \%$ & $\begin{array}{l}2 \% \text { or } \$ 4,000 \\
4 \% \text { on next } \$ 4,000 \\
6 \% \text { on balance }\end{array}$ & both & same \\
\hline 1925 & $1926 \ldots .$. & $13 \%$ & $\begin{array}{l}112 \% \text { on } \$ 4,000 \\
3 \% \text { on pext } \$ 4,000 \\
5 \% \text { an balance }\end{array}$ & both & same \\
\hline $\begin{array}{l}1926-1927 \\
1928\end{array}$ & $\begin{array}{r}1926 \ldots \ldots \\
\ldots \ldots\end{array}$ & $13 \%$ & some & both & same \\
\hline x930-1931 & 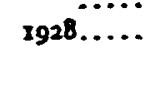 & $12 \%$ & $\operatorname{san}$ & both & $\begin{array}{l}\$ 3,000 \text { if act } \\
\text { ineome leas } \\
\text { than } \$ 25,000\end{array}$ \\
\hline 2929 & $\begin{array}{c}\text { 1928-JtRes. } \\
\text { 1929...... }\end{array}$ & $12 \%$ & $\begin{array}{l}1 / 2 \% \text { on } \$ 4,000 \\
2 \% \text { on pext } \$ 4,000 \\
4 \% \text { on balance }\end{array}$ & both. & ame \\
\hline $1932-1933$ & $1932 \ldots$. & $13 \% \%$ & $\begin{array}{l}1 \% \text { on } \$ 4,000 \\
8 \% \text { on balance }\end{array}$ & both & Done \\
\hline $\begin{array}{l}\text { 1934-1935 } \\
\text { (never } \\
\text { effective) }\end{array}$ & $\begin{array}{l}1934 \ldots \ldots \\
1934-1935\end{array}$ & $\begin{array}{r}13 \% 4 \% \\
121 / 2-15 \%\end{array}$ & $\begin{array}{l}1 \% \\
4 \%\end{array}$ & $\begin{array}{l}\text { both } \\
\text { too\% to indi- } \\
\text { viduals. } 90 \%\end{array}$ & $\begin{array}{l}\text { nope } \\
\text { none }\end{array}$ \\
\hline $1936-1937$ & $1936 \ldots .$. & B-15\% & $4 \%$ & $\begin{array}{l}\text { No corph } \\
\text { None to indi- } \\
\text { viduals. } 85 \% \\
\text { to corpe. }\end{array}$ & none \\
\hline $\begin{array}{l}1938-1939 \\
1940-\end{array}$ & $\begin{array}{l}1938 \ldots \ldots \\
1939^{*} \ldots \ldots\end{array}$ & $\begin{array}{c}121 / 2-161 / 2 \% \\
121 / 2-18 \%\end{array}$ & $\begin{array}{l}4 \% \\
4 \%\end{array}$ & $\begin{array}{l}\text { same } \\
\text { same }\end{array}$ & $\begin{array}{l}\text { nope } \\
\text { node }\end{array}$ \\
\hline
\end{tabular}

- This table does not include excess profis axes or pinalty taxes for unreasorable accumulation of sirplus or taxes on special types of corporations such as personal bolding companies.

These rates do not include the additional tax of 7 to $27 \%$ on indistributed profin.

These rates do not include the additional tax of $2 \% \%$ on undistributed profita.

- Interaal Rerenue Ccie. 